\title{
Ukuran Pemusatan Rata-rata
}

\author{
Ahmad Sudi Pratikno ${ }^{1,2^{*}}$, Agitia Ayu Prastiwi ${ }^{1}$ dan Sila Ramahwati ${ }^{1}$ \\ ${ }^{1}$ Department of Elementary Education, Graduate School, Yogyakarta State University, Yogyakarta 55281, Indonesia \\ ${ }^{2}$ Department of Elementary Teacher Education, Faculty of Education, University of Trunojoyo Madura, Bangkalan, East Java 69162, \\ Indonesia \\ *E-mail: ahmad.pratikno@trunojoyo.ac.id
}

Received 02 October 2016

Accepted 12 January 2018

Published 28 February 2022

\section{Abstract}

Calculating the research results especially for social science research is quite difficult. This is because the results of social science research is different from scientific research which commonly give direct effect toward treatment. In mapping the social science results for example the effect of experimental method on students' insight is using qualitative research method in analyzing. In this article, we gave sample research in analyzing mean, median, and modus. However, we use the manual technique because we exercise the expert skill in counting the mathematic number. Furthermore, to expand and give a valid result on social science research, we suggest to use computational applications such SPSS and Microsoft Excel. In the end, we declare that there are more complexity in conducting social science research, meanwhile researchers can use some applications in analyzing the result and conclude it.

Keywords: mapping, data centre, mean, median, modus, frequency, distribution, statistic

\section{Rata-rata}

Rata-rata dapat disebut juga rataan. Macam rata-rata di antaranya adalah rata-rata hitung, rata-rata ukur dan ratarata harmonis.

a. Rata-rata Hitung

Yang biasanya disebut rata-rata dalam percakapan sehari-hari itu adalah rata-rata hitung. Rata-rata hitung populasi dinyatakan dengan lambang $\mu$ dibaca "mu", sedangkan rata-rata hitung sampel dinyatakan dengan lambang $\bar{x}$ (dibaca "x bar" atau "x garis") huruf tidak hanya $x$, tetapi bisa $y$ dan sebagainya tergantung lambang yang digunakan untuk menyatakan peubah yang sedang dicari rataratanya (Pratikno, Prastiwi, \& Ramahwati, 2020).

Notasi : $\quad \mu$ : rata-rata hitung populasi $\bar{x}$ : rata-rata hitung sampel

1) Rata-Rata Hitung untuk Data Tunggal

$$
\mu=\frac{\sum_{i=1}^{N} x_{i}}{N}
$$$$
\operatorname{dan} \bar{x}=\frac{\sum_{i=1}^{n} x_{i}}{n}
$$

$\mu$ : rata-rata hitung populasi

$\mathrm{N}$ : ukuran Populasi

$\bar{x}$ : rata-rata hitung sampel

$\mathrm{n}$ : ukuran Sampel $\mathrm{x}_{\mathrm{i}}$ : data ke-i

Contoh:

Misalnya diketahui di kota A hanya terdapat 6 PTS, masing-masing tercatat mempunyai banyak mahasiswa sebagai berikut: 850, 1100, 1150, 1250, 750,900 . Berapakah rata-rata banyak mahasiswa PTS di kota A?

Rata-rata Populasi atau Sampel?

Jawab:

$$
\mu=\frac{6000}{6}=1000
$$

b. Rata-rata untuk Data Kelompok

Nilainya merupakan pendekatan. Biasanya berhubungan dengan rata-rata hitung sampel

$\bar{x}=\frac{\sum_{i=1}^{n} f_{i} x_{i}}{\sum_{i=1}^{n} f_{i}}$ sehingga :

$$
\bar{x}=\frac{\sum_{i=1}^{n} f_{i} x_{i}}{n}
$$

$\bar{x}$ : rata-rata hitung sampel

n : ukuran Sampel

fi : frekuensi di kelas ke-i

xi : Titik Tengah Kelas ke-i 


\begin{tabular}{cccc}
\hline Kelas & $\begin{array}{c}\text { Titik Tengah } \\
\text { Kelas }\left(\mathbf{x}_{\mathbf{i}}\right)\end{array}$ & $\begin{array}{c}\text { Frekuensi } \\
\left(\mathbf{f}_{\mathbf{i}}\right)\end{array}$ & $\mathbf{f}_{\mathbf{i}} \mathbf{x}_{\mathbf{i}}$ \\
\hline $16-23$ & 19.5 & 10 & 195 \\
\hline $24-31$ & 27.5 & 17 & 467.5 \\
\hline $32-39$ & 35.5 & 7 & 248.5 \\
\hline $40-47$ & 43.5 & 10 & 435 \\
\hline $48-55$ & 51.5 & 3 & 154.5 \\
\hline $56-63$ & 59.5 & 3 & 178.5 \\
\hline Jumlah $(\Sigma)$ & & 50 & 1679 \\
\hline
\end{tabular}

Jawab : $\bar{x}=\frac{1679}{50}=33.58$

Selain dengan rumus tersebut, dapat dicari dengan suatu nilai dugaan (M)

$\bar{x}=M+\frac{\sum_{i=1}^{n} f_{i} d_{i}}{n}$

$\mathrm{d}_{\mathrm{i}}: \operatorname{TTKi}\left(\mathrm{x}_{\mathrm{i}}\right)-\mathrm{M}$

\begin{tabular}{cccccc}
\hline Kelas & $\begin{array}{c}\text { Titik } \\
\text { Tengah } \\
\text { Kelas }\left(\mathbf{x}_{\mathbf{i}}\right)\end{array}$ & $\mathbf{M}$ & $\mathbf{D}_{\mathbf{i}}$ & $\begin{array}{c}\text { Freku- } \\
\mathbf{e n s i} \\
\left.\mathbf{( f}_{\mathbf{i}}\right)\end{array}$ & $\mathbf{f}_{\mathbf{i}} \mathbf{d}_{\mathbf{i}}$ \\
\hline $16-23$ & 19.5 & 39.5 & -20 & 10 & -200 \\
\hline $24-31$ & 27.5 & 39.5 & -12 & 17 & -204 \\
\hline $32-39$ & 35.5 & 39.5 & -4 & 7 & -28 \\
\hline $40-47$ & 43.5 & 39.5 & 4 & 10 & 40 \\
\hline $48-55$ & 51.5 & 39.5 & 12 & 3 & 36 \\
\hline $56-63$ & 59.5 & 39.5 & 20 & 3 & 60 \\
\hline $\begin{array}{c}\text { Jumlah } \\
(\Sigma)\end{array}$ & & & 0 & 50 & -296 \\
\hline
\end{tabular}

Jawab:

$$
\bar{x}=M+\frac{\sum_{i=1}^{n} f_{i} d_{i}}{n}=39.5+\frac{-295}{50}=39.5-5.92=33.58
$$

Catatan: Bagaimana menentukan M?

Tidak ada cara khusus, $M$ dapat ditentukan sembarang! atau $\mathrm{M}$ dapat ditentukan dengan Titik Tengah Kelas $\left(\mathrm{x}_{\mathrm{i}}\right)$.

- jika banyak kelas $(\mathrm{k})$ ganjil maka ambil $\left(\mathrm{x}_{\mathrm{i}}\right)$ pada kelas ke $\left\lceil\frac{k}{2}\right\rceil$ (kelas yang di tengah-tengah)

- jika banyak kelas $(\mathrm{k})$ genap maka gunakan $\left(\mathrm{x}_{\mathrm{i}}\right)$ pada kelas ke $\frac{k}{2}$ dan kelas ke $\frac{k}{2}+1$ selanjutnya kedua nilai $\left(\mathrm{x}_{\mathrm{i}}\right)$ tersebut dibagi dua

c. Rata-rata Ukur

Misalkan terdapat $\mathrm{n}$ data yang terdiri dari $x_{1}, x_{2}, x_{3}, x_{4}, \ldots ., x_{n}$, maka rata-rata ukur didefinisikan sebagai
$U=\sqrt[n]{x_{1} \cdot x_{2} \cdot x_{3} \cdot x_{4} \ldots \ldots x_{5}}$ yaitu akar pangkat $\mathrm{n}$ dari perkalian $x_{1} \cdot x_{2} \cdot x_{3} \cdot x_{4}, \ldots, x_{n}$.

Rata-rata ukur disebut juga rata-rata geometrik. Jika perbandingan tiap data berurutan tetap atau hampir tetap, rata-rata ukur lebih baik digunakan daripada rata-rata hitung. Rata-rata ukur terutama digunakan untuk merata-ratakan data yang rasio suku-suku berurutan kira-kira tetap. Biasanya digunakan pada data yang berupa laju perubahan, pertumbuhan, indeks ekonomi.

Untuk bilangan-bilangan bernilai besar, rata-rata ukur dapat ditentukan dengan rumus:

$\log U=\frac{\sum \log x_{i}}{n}$

Jika data disusun dalam daftar distribusi frekuensi rata-r ata ukurnya dinyatakan dengan menggunakan rumus

$\log U=\frac{\sum\left(f_{i} \log x_{i}\right)}{\sum f_{i}}$

dimana

$x_{i}$ : tanda kelas

$f_{i}$ : frekuensi yang sesuai dengan $x_{i}$

Contoh:

Dalam bentuk paling sederhana, jika diketahui 3 buah data masing-masing 2, 4, 8 maka rata-rata ukurnya adalah:

$$
\begin{aligned}
& U=\sqrt[n]{x_{1} \cdot x_{2} \cdot x_{3} \cdot x_{4} \ldots \ldots x_{n}}, \text { sehingga } \\
& U=\sqrt[3]{(2)(4)(8)} \\
& U=\sqrt[3]{64} \\
& U=4
\end{aligned}
$$

Rata-rata ukur untuk data yang tersusun dalam daftar distribusi dibawah ini adalah:

\begin{tabular}{ccccc}
\hline Kelas Interval & $f_{i}$ & $x_{i}$ & $\log x_{i}$ & $f_{i} \log x_{i}$ \\
\hline $13,0-17,4$ & 2 & 15,2 & 1,18 & 2,36 \\
\hline $17,5-21,9$ & 3 & 19,7 & 1,30 & 3,90 \\
\hline $22,0-26,4$ & 1 & 24,2 & 1,38 & 1,38 \\
\hline $26,5-29,9$ & 10 & 28,7 & 1,46 & 14,60 \\
\hline $31,0-35,4$ & 28 & 33,2 & 1,52 & 42,56 \\
\hline $35,5-39,9$ & 18 & 37,7 & 1,58 & 28,44 \\
\hline $40,0-44,4$ & 13 & 42,2 & 1,63 & 21,19 \\
\hline Jumlah & 75 & & & 114,43 \\
\hline
\end{tabular}

$\log U=\frac{\sum\left(f_{i} \log x_{i}\right)}{\sum f_{i}}$

$\log U=\frac{2,36+3,90+1,38+14,60+42,56+28,44+21,19}{75}$

$\log U=\frac{114,43}{75}$ 


$$
\begin{aligned}
\log U & =1,525733 \ldots . \\
U & =33,55
\end{aligned}
$$

d. Rata-rata Harmonis

Rata-rata harmonis disebut juga rata-rata selaras. Misalkan terdapat $\mathrm{n}$ data yang terdiri dari $x_{1}, x_{2}, x_{3} x_{4}, \ldots . ., x_{n}$, maka rata-rata harmonis didefinisikan sebagai:

$$
H=\frac{n}{\frac{1}{x_{1}}+\frac{1}{x_{2}}+\frac{1}{x_{3}}+\ldots . .+\frac{1}{x_{n}}}
$$

atau

$$
H=\frac{n}{\sum\left(\frac{1}{x_{i}}\right)}
$$

Jika data tersusun dalam daftar distribusi frekuensi, maka rata-rata harmonis dinyatakan dengan:

$$
H=\frac{\sum f_{i}}{\sum\left(\frac{f_{i}}{x_{i}}\right)}
$$

dimana

$x_{i}:$ tanda kelas

$f_{i}$ : frekuensi yang sesuai dengan $x_{i}$

Secara umum, untuk sekumpulan data berlaku $H \leq U \leq \bar{X}$

Contoh

Nilai 10 mahasiswa yang mengikuti kuliah statistika di Jurusan Pendidikan Matematika IKIP Budi Utomo Malang adalah sebagai berikut: 56, 76, 34, 59, 62, 56, 68, 60, 73, dan 81.

Rata-rata harmonis diperoleh

$$
H=\frac{n}{\sum\left(\frac{1}{x_{i}}\right)}
$$$$
H=\frac{10}{\left(\frac{1}{56}\right)+\left(\frac{1}{76}\right)+\left(\frac{1}{34}\right)+\left(\frac{1}{59}\right)+\left(\frac{1}{62}\right)+\left(\frac{1}{56}\right)+\left(\frac{1}{68}\right)+\left(\frac{1}{60}\right)+\left(\frac{1}{73}\right)+\left(\frac{1}{81}\right)}
$$

$H=\frac{10}{0,018+0,013+0,029+0,017+0,016+0,018+0,015+0,017+0,014+0,012}$ $H=\frac{10}{0,169}$

$H=59,17$

Jika data disusun dalam daftar distribusi di bawah ini,

\begin{tabular}{cccc}
\hline Kelas Interval & $f_{i}$ & $x_{i}$ & $\frac{f_{i}}{x_{i}}$ \\
\hline $13,0-17,4$ & 2 & 15,2 & 0,13 \\
\hline $17,5-21,9$ & 3 & 19,7 & 0,15 \\
\hline $22,0-26,4$ & 1 & 24,2 & 0,04 \\
\hline $26,5-29,9$ & 10 & 28,7 & 0,35 \\
\hline $31,0-35,4$ & 28 & 33,2 & 0,84 \\
\hline $35,5-39,9$ & 18 & 37,7 & 0,48 \\
\hline
\end{tabular}

\begin{tabular}{cccc}
\hline Kelas Interval & $f_{i}$ & $x_{i}$ & $\frac{f_{i}}{x_{i}}$ \\
\hline $40,0-44,4$ & 13 & 42,2 & 0,31 \\
\hline Jumlah & 75 & & 2,3 \\
\hline
\end{tabular}

maka rata-rata harmonik ditentukan oleh

$$
H=\frac{\sum f_{i}}{\sum\left(\frac{f_{i}}{x_{i}}\right)}
$$

sehingga

$$
H=\frac{75}{2,3}
$$

Rata-rata harmonik data di atas adalah $H=32,61$

\section{Kesimpulan}

Dalam penghitungan data penelitian, rata-rata (mean) sering kita jumpai untuk menentukan besaran angka yang merepresentasikan hasil dari setiap objek atau subjek yang diteliti ditinjau secara holistik. Rata-rata hitung menghitung rata-rata populasi, rata-rata data kelompok menghitung rata-rata diantara dua kelompok yang akan dianalisis komparasi atau persamaannya (Pratikno, 2020). Rata-rata ukur adalah akar pangkat dari perkalian dari data nilai (skor) subjek penelitian, sedangkan ratarata harmonis (rata-rata selaras, atau rata-rata harmonik) adalah rata-rata dari jumlah data dibagi dengan 1/skor data setiap sampel. Secara lebih rinci dapat dilihat pada pembahasan di subbab sebelumnya.

\section{Saran}

Penyusun menyadari bahwa artikel ini diperlukan beberapa revisi demi perbaikan yang mencakup materi modus dan median. Oleh karena itu, penulis mengharapkan kritik dan saran yang membangun agar semakin baik dalam menyusun artikel-artikel pada kesempatan berikutnya.

\section{DAFTAR PUSTAKA}

PPS UNY. (2011). Statistika: Matrikulasi S2 Program Pascasarjana UNY. Yogyakarta: UNY.

Pratikno, A. S., Prastiwi, A. A., \& Ramahwati, S. (2020). Pemetaan ukuran pemusatan data. OSF Preprints, 25(03), 2-3. https://doi.org/10.31219/osf.io/v3n9h, Retrieved from: https://osf.io/v3n9h/

Pratikno, A. S. (2020). Penyajian data, jenis data, dan variasi data. OSF Preprints, 25(03), 1-4, https://doi.org/10.31219/osf.io/7w8xp, Retrieved from: https://osf.io/7w8xp/

Sudjana. (2005). Metode Statistika. Bandung: Tarsito. 
(c) (9)(2) $(2020$ by the authors. Submitted for (c) $\$($ ) possible open access publication under the BY NC SA terms and conditions of the Creative Commons Attribution (CC BY) license (http://creativecommons. org/licenses/by/4.0/). 